\title{
Characterization of Fusarium oxysporum Isolates Obtained from Cucumber in China by Pathogenicity, VCG, and RAPD
}

D. J. Vakalounakis, National Agricultural Research Foundation (N.AG.RE.F.), Plant Protection Institute, P.O. Box 2228, 71003 Heraklio, Crete, Greece; Z. Wang, Zhejiang University, College of Agriculture and Biotechnology, Biotechnology Institute, 268 Kaixuan Rd., Hangzhou 310029, China; G. A. Fragkiadakis, N.AG.RE.F., Plant Protection Institute, P.O. Box 2228, 71003 Heraklio, Crete, Greece; G. N. Skaracis, Hellenic Sugar-Industry, Department of Plant Breeding \& Biotechnology, 57400 Sindos, Greece; D.-B. Li, Zhejiang University, College of Agriculture and Biotechnology, Biotechnology Institute, 268 Kaixuan Rd., Hangzhou 310029, China

\begin{abstract}
Vakalounakis, D. J., Wang, Z., Fragkiadakis, G. A., Skaracis, G. N., and Li, D.-B. 2004. Characterization of Fusarium oxysporum isolates obtained from cucumber in China by pathogenicity, VCG, and RAPD. Plant Dis. 88:645-649.

Thirty-four isolates of Fusarium oxysporum, obtained in China from cucumber plants showing either Fusarium wilt (F. oxysporum f. sp. cucumerinum) or root and stem rot (F. oxysporum f. sp. radicis-cucumerinum) symptoms, were characterized by pathogenicity, vegetative compatibility, and random amplified polymorphic DNA (RAPD). Of these, 23 isolates were identified by pathogenicity as $F$. oxysporum $\mathrm{f}$. sp. cucumerinum, and one as $F$. oxysporum f. sp. radicisсиситеrinum, while 10 isolates were avirulent on cucumber, melon, sponge gourd, and pumpkin. The Chinese isolates of $F$. oxysporum $\mathrm{f}$. sp. cucumerinum were assigned to RAPD groups III and XXI and to vegetative compatibility group (VCG) 0183, four new VCGs, 0184 to 0187, and a single-member VCG included in the artificial VCG 018-. The Chinese isolate of $F$. oxysporum f. sp. radicis-cucumerinum was assigned to RAPD group I and bridging VCG 0260/0261. The occurrence of $F$. oxysporum f. sp. radicis-cucumerinum on cucumber is reported for the first time in China.
\end{abstract}

Cucumber (Cucumis sativus L.) is a crop of significant economic importance in many countries (21). It is affected by several fungal pathogens, and Fusarium oxysporum Schlechtend.:Fr. is among the most important (21). On cucumber, two formae speciales of $F$. oxysporum have been described, F. oxysporum f. sp. сисиmerinum J.H. Owen, causing Fusarium wilt (12), and F. oxysporum f. sp. radiciscucumerinum D.J. Vakalounakis, causing root and stem rot (16,22-24).

Fusarium wilt of cucumber is a serious vascular disease worldwide, including in Greece and China $(1,21)$. Armstrong et al. (2) proposed three races of $F$. oxysporum $\mathrm{f}$. sp. cucumerinum, to be called races 1,2 , and 3, mainly occurring in the United States, Israel, and Japan, respectively $(7,15)$. Root and stem rot of cucumber was described for the first time during 1989-90 in Crete as causing severe losses in greenhouse crops (22). The disease was also recorded in Canada in $1994(4,18)$, in France in 1998 (19), and in Spain in 2000

Corresponding author: Demetrios J. Vakalounakis E-mail: vakalounakis@ nagref.gr

Accepted for publication 22 January 2004.

Publication no. D-2004-0402-02R

(C) 2004 The American Phytopathological Society
(14), where significant yield losses were encountered $(23,24)$. No races of $F$. oxyet been identified (22-24).

The genetic variation of 106 isolates of $F$. oxysporum from cucumber has been studied with respect to pathogenicity, vegetative compatibility grouping, and random amplified polymorphic DNA (RAPD) analysis (23). Isolates of $F$. oxysporum $\mathrm{f}$. sp. radicis-cucumerinum were assigned to vegetative compatibility groups (VCGs) 0260, 0261, and 0260/0261 (bridging isolates) as well as to a single RAPD group (I) (23). Isolates of $F$. oxysporum f. sp. cucumerinum were assigned to VCGs 0180 to 0183 and to four single-member VCGs (018-) as well as to two different RAPD groups (II, III), while vegetatively selfincompatible (HIS) isolates were also recorded (23).

In the present study, we used pathogenicity, VCGs, and RAPD-PCR to characterize 34 isolates of $F$. oxysporum from China obtained from cucumber plants showing symptoms of either Fusarium wilt (33 isolates) or root and stem rot (one isolate). Our objectives were to: (i) identify these isolates at the forma specialis level, (ii) investigate whether $F$. oxysporum f. sp. radicis-cucumerinum occurs in China, and (iii) examine genetic relatedness among the Chinese isolates of $F$. oxysporum from cucumber, and compare them with previysporum f. sp. radicis-cucumerinum have ously characterized isolates of $F$. oxysporum from cucumber, by VCG and RAPD analyses.

\section{MATERIALS AND METHODS}

Fungal isolates. Isolates of $F$. oxysporum were recovered from diseased cucumber plants, showing either typical Fusarium wilt or root and stem rot symptoms, from seven provinces of China, which represent different geographical regions, between the years 1998 and 2000 (Table 1). Small pieces of discolored vascular tissue from the lower part of the stems of diseased plants were plated on acidified potato dextrose agar (APDA, 4.5 $\mathrm{ml} \mathrm{25 \%} \mathrm{lactic} \mathrm{acid} \mathrm{in} 1$ liter PDA, final $\mathrm{pH}$ 4.0) and incubated at $25 \pm 0.5^{\circ} \mathrm{C}$ in the dark for 4 days. Isolates were identified as F. oxysporum by morphological criteria (3). A single microconidial culture was prepared from each isolate.

Pathogenicity tests. Pathogenicity of $F$. oxysporum isolates was tested as previously described $(22,23)$ by root dip inoculation on seedlings at the two-true-leaf stage of four differential cucurbit species: cucumber cv. Knossos, melon (Cucumis melo L.) cv. Moulkeiko, sponge gourd (Luffa aegyptiaca Mill.), and pumpkin (Cucurbita maxima Duchesne $\times$ C. moschata Duch. ex Lam.). Final observation on disease development was made 30 days after inoculation. For each isolate and differential host, eight replicate plants were used. Tests were repeated once. Disease severity was assessed with a 0 to 3 visual scale, where $0=$ no symptoms, $1=$ light or moderate wilt, light vascular discoloration in the stem, 2 = severe wilt, vascular discoloration in the stem, and $3=$ dead seedlings. To confirm infection of cucurbit plants by $F$. oxysporum, isolations were made from each plant with or without symptoms.

Vegetative compatibility tests. Tests were based on the ability of nitrate reductase (nit) mutants of $F$. oxysporum to form a heterokaryon and to grow on a nitratecontaining medium (17). Mutants from each Chinese $F$. oxysporum isolate from cucumber were generated on a minimal medium (FMM) amended with $1.5 \%$ potassium chlorate (FMMC) (17) and charac- 
terized as nit1, nit3, or NitM (5). Representative nit mutants (nit1, nit3, and NitM) from all isolates were paired with tester strains of $F$. oxysporum f. sp. cucumerinum and $F$. oxysporum f. $\mathrm{sp}$. radiciscucumerinum. These were as follows: $F$. oxysporum f. sp. cucumerinum: (a) tester strains of the four known VCGs 0180 (FOCU 56L/12 and FOCU 57N/18, both NitM), 0181 (NETH 10782A-2 and NETH
10782A-5, both NitM), 0182 (ATCC 36332B-1 and ATCC 36332B-2, NitM and nit1, respectively), and 0183 (FOC-1-9A-2 and FOC-1-9A-4, both NitM); (b) tester strains of the artificial VCG 018-, which consisted of the four single-member VCGs $\mathrm{Cu}: 6-0(\mathrm{Cu}: 6-0-6 \mathrm{~A}-3$ and $\mathrm{Cu}: 6-0-6 \mathrm{~A}-12$, both NitM), Tf-213 (Tf-213-2A-3 and Tf213-2A-6, nit1 and NitM, respectively), Tf-304 (Tf-304-3A-2 and Tf-304-3A-4, both NitM), and Tf-579 (Tf-579-4A-1 and Tf-579-4A-6, NitM and nit1, respectively) (23). F. oxysporum f. $\mathrm{sp}$. radiciscucumerinum: tester strains of the two known VCGs 0260 (AFu-15B-2 and AFu14A-4, both NitM) and 0261 (AFu-4C-8 and $\mathrm{AFu}-4 \mathrm{C}-9$, NitM and nitl, respectively) (23). The sources of these tester strains were the Mycology Laboratory of the Plant Protection Institute of Heraklio,

Table 1. Isolates of Fusarium oxysporum from cucumber obtained from various locations in China and used in this study, listed by origin, forma specialis, vegetative compatibility group (VCG), pathogenicity, and random amplified polymorphic DNA (RAPD) group

\begin{tabular}{|c|c|c|c|c|c|c|c|}
\hline \multirow[b]{2}{*}{ Isolate } & \multirow{2}{*}{$\begin{array}{c}\text { Origin } \\
\text { (province/location) }\end{array}$} & \multirow{2}{*}{$\begin{array}{l}\text { Year of } \\
\text { isolation }\end{array}$} & \multicolumn{4}{|c|}{ Disease index $^{a}$} & \multirow[b]{2}{*}{ RAPD group ${ }^{b}$} \\
\hline & & & Cucumber & Melon & Sponge gourd & Pumpkin & \\
\hline \multicolumn{8}{|c|}{ Fusarium oxysporum f. sp. cucumerinum } \\
\hline \multicolumn{8}{|c|}{ VCG $0183^{c}$} \\
\hline 0014 & Beijing/Haidian & 2000 & $2.8(100)$ & $0.0(0)$ & $0.0(0)$ & $0.0(0)$ & III \\
\hline 0018 & Xingjiang/Kuitun & 2000 & $3.0(100)$ & $0.0(0)$ & $0.0(0)$ & $0.0(0)$ & III \\
\hline 0019 & Xingjiang/Kuitun & 2000 & $2.8(100)$ & $0.0(0)$ & $0.0(0)$ & $0.0(0)$ & III \\
\hline \multicolumn{8}{|c|}{ VCG 0184 (new) } \\
\hline Tf-579d & Japan & 1996 & $2.8(92)$ & $0.0(0)$ & $0.0(0)$ & $0.0(0)$ & III \\
\hline $9906-1$ & Zhejiang/Zhoushan & 1999 & $2.1(73)$ & $0.0(0)$ & $0.0(0)$ & $0.0(0)$ & III \\
\hline $9906-2$ & Zhejiang/Zhoushan & 1999 & $2.3(75)$ & $0.0(0)$ & $0.0(0)$ & $0.0(0)$ & III \\
\hline $9906-3$ & Zhejiang/Zhoushan & 1999 & $1.5(67)$ & $0.0(0)$ & $0.0(0)$ & $0.0(0)$ & III \\
\hline \multicolumn{8}{|c|}{ VCG 0185 (new) } \\
\hline Tf- $213^{\mathrm{d}}$ & Japan & 1985 & $2.8(92)$ & $0.0(0)$ & $0.0(0)$ & $0.0(0)$ & III \\
\hline $9909-2$ & Heilongjiang/Shangzhi & 1999 & $1.2(42)$ & $0.0(0)$ & $0.0(0)$ & $0.0(0)$ & III \\
\hline \multicolumn{8}{|c|}{ VCG 0186 (new) } \\
\hline 9901-1 & Gansu/Langzhou & 1999 & $1.5(67)$ & $0.0(0)$ & $0.0(0)$ & $0.0(0)$ & XXI \\
\hline $9901-2$ & Gansu/Langzhou & 1999 & $0.8(58)$ & $0.0(0)$ & $0.0(0)$ & $0.0(0)$ & XXI \\
\hline $9902-1$ & Gansu/Langzhou & 1999 & $1.5(67)$ & $0.0(0)$ & $0.0(0)$ & $0.0(0)$ & XXI \\
\hline $9902-2$ & Gansu/Langzhou & 1999 & $1.5(50)$ & $0.0(0)$ & $0.0(0)$ & $0.0(0)$ & XXI \\
\hline $9903-1$ & Gansu/Langzhou & 1999 & $1.1(42)$ & $0.0(0)$ & $0.0(0)$ & $0.0(0)$ & XXI \\
\hline $9903-2$ & Gansu/Langzhou & 1999 & $0.8(58)$ & $0.0(0)$ & $0.0(0)$ & $0.0(0)$ & XXI \\
\hline 9904-1 & Gansu/Langzhou & 1999 & $2.3(75)$ & $0.0(0)$ & $0.0(0)$ & $0.0(0)$ & XXI \\
\hline $9904-2$ & Gansu/Langzhou & 1999 & $1.8(58)$ & $0.0(0)$ & $0.0(0)$ & $0.0(0)$ & XXI \\
\hline 9904-3 & Gansu/Langzhou & 1999 & $2.0(67)$ & $0.0(0)$ & $0.0(0)$ & $0.0(0)$ & XXI \\
\hline $9905-0$ & Gansu/Langzhou & 1999 & $1.3(58)$ & $0.0(0)$ & $0.0(0)$ & $0.0(0)$ & XXI \\
\hline $9909-3$ & Heilongjiang/Shangzhi & 1999 & $2.0(67)$ & $0.0(0)$ & $0.0(0)$ & $0.0(0)$ & $n t^{e}$ \\
\hline \multicolumn{8}{|c|}{ VCG 0187 (new) } \\
\hline 0016 & Zhejiang/Hangzhou & 2000 & $2.8(100)$ & $0.0(0)$ & $0.0(0)$ & $0.0(0)$ & III \\
\hline 0017 & Zhejiang/Hangzhou & 2000 & $3.0(100)$ & $0.0(0)$ & $0.0(0)$ & $0.0(0)$ & III \\
\hline 0020 & Zhejiang/Hangzhou & 2000 & $2.1(82)$ & $0.0(0)$ & $0.0(0)$ & $0.0(0)$ & III \\
\hline \multicolumn{8}{|l|}{ VCG 018- } \\
\hline Tf-304 & Japan & 1985 & $2.7(100)$ & $0.0(0)$ & $0.0(0)$ & $0.0(0)$ & III \\
\hline $\mathrm{Cu}: 6-0^{\mathrm{d}}$ & Japan & - & $2.6(100)$ & $0.0(0)$ & $0.0(0)$ & $0.0(0)$ & III \\
\hline 9806 & Jiangsu/Nanjing & 1998 & $1.0(33)$ & $0.0(0)$ & $0.0(0)$ & $0.0(0)$ & III \\
\hline \multicolumn{8}{|l|}{ 018-HSI } \\
\hline FHG 9801 & Zhejiang/Ningbo & 1998 & $0.8(20)$ & $0.0(0)$ & $0.0(0)$ & $0.0(0)$ & III \\
\hline \multicolumn{8}{|c|}{ F. oxysporum f. sp. radicis-cucumerinum } \\
\hline \multicolumn{8}{|c|}{ VCG 0260/0261 (bridging group) } \\
\hline $9909-1$ & Heilongjiang/Shangzhi & 1999 & $1.8(58)$ & $1.8(83)$ & $1.7(70)$ & $0.0(0)$ & I \\
\hline Fisher's LSD & & & 0.62 & & & & \\
\hline \multicolumn{8}{|c|}{ Avirulent isolates of $F$. oxysporum from China obtained from cucumber } \\
\hline 9802 & Zhejiang/Hangzhou & 1998 & $0.0(0)$ & $0.0(0)$ & $0.0(0)$ & $0.0(0)$ & XXII \\
\hline 9803 & Zhejiang/Hangzhou & 1998 & $0.0(0)$ & $0.0(0)$ & $0.0(0)$ & $0.0(0)$ & XXIII \\
\hline 9804 & Zhejiang/Hangzhou & 1998 & $0.0(0)$ & $0.0(0)$ & $0.0(0)$ & $0.0(0)$ & XXIV \\
\hline 9805 & Jiangsu/Zhenjiang & 1998 & $0.0(0)$ & $0.0(0)$ & $0.0(0)$ & $0.0(0)$ & XXV \\
\hline 9807 & Jiangsu/Zhenjiang & 1998 & $0.0(0)$ & $0.0(0)$ & $0.0(0)$ & $0.0(0)$ & XXVI \\
\hline $9907-3$ & Jiangsu/Zhenjiang & 1998 & $0.0(0)$ & $0.0(0)$ & $0.0(0)$ & $0.0(0)$ & XXVII \\
\hline 0011 & Zhejiang/Daxuemiaopu & 2000 & $0.0(0)$ & $0.0(0)$ & $0.0(0)$ & $0.0(0)$ & XXVIII \\
\hline 0012 & Guangxi/Qingzhou & 2000 & $0.0(0)$ & $0.0(0)$ & $0.0(0)$ & $0.0(0)$ & XXIX \\
\hline 0013 & Guangxi/Qingzhou & 2000 & $0.0(0)$ & $0.0(0)$ & $0.0(0)$ & $0.0(0)$ & $\mathrm{XXX}$ \\
\hline 0015 & Zhejiang/Daxuenongchang & 2000 & $0.0(0)$ & $0.0(0)$ & $0.0(0)$ & $0.0(0)$ & XXXI \\
\hline
\end{tabular}

${ }^{a}$ Disease index was the mean disease severity value on artificially inoculated plants, which was calculated as described in Materials and Methods. Numbers in parentheses indicate percentage of diseased seedlings. Pathogenicity tests were carried out for each isolate.

${ }^{b}$ As determined by RAPD-PCR using eight arbitrary primers.

${ }^{\mathrm{c}}$ Vegetative compatibility groups (VCGs) as determined in this study and numbered according to the system adopted by Puhalla (17) and further standardized by Kistler et al. (11). VCG numbering system, in which $026 \#=$ VCG code for $F$. oxysporum $\mathrm{f}$. sp. radicis-cucumerinum as suggested by Vakalounakis and Fragkiadakis (23); 018\# = VCG code for F. oxysporum f. sp. cucumerinum as suggested by Katan et al. (9); 018- = an artificial group containing single-member VCGs of F. oxysporum f. sp. cucumerinum; 018-HIS = an artificial group containing heterokaryon self-incompatible isolates that did not form heterokaryons upon pairing with themselves or with any of the other isolates.

${ }^{\mathrm{d}}$ Isolates included in previous publications: Tf-213 (22), Tf-304 (22), Tf-579 (22).

e Not tested. 
Crete, Greece, and the American Type Culture Collection (ATCC). Complementation tests were made on $\mathrm{FMM}$ at $23^{\circ} \mathrm{C}$ in the dark (17). Heterokaryon formation was evident after 7 to 20 days by the formation of a wild-type mycelium at the contact zone between two nit mutants (17). Absence of wild-type growth between nit mutants derived from the same parent isolate indicated allelic, overlapping, or otherwise noncomplementary mutations or vegetative self-incompatibility (9), whereas absence of wild-type growth between nit mutants from different parent isolates indicated either noncomplementarity or inability to form heterokaryons due to lack of vegetative compatibility (9). An isolate was assigned to a given VCG if it was capable of producing robust heterokaryon with at least one other isolate of the same VCG.

RAPD-PCR analysis. DNA preparation and RAPD-PCR were carried out as previously described (23) using the primers OPA-01, OPB-01, OPB-4, OPB-7, OPB-8, OPB-14, OPB-20, and OPF-05 (Operon Technologies, Inc., Alameda, CA) (Table 2), which had been found (23) to generate banding patterns capable of differentiating $F$. oxysporum f. sp. cucumerinum and $F$. oxysporum f. $\mathrm{sp}$. radicis-cucumerinum isolates. Amplified DNA was electrophoresed in $1.2 \%$ agarose gels, stained with ethidium bromide, and photographed under UV light (302 nm) (23). The PCR reactions were carried out at least three times, using different DNA extracts from each of the isolates tested.

Data analysis. Pathogenicity tests were conducted in a completely randomized design. Disease index data of all virulent Chinese isolates of $F$. oxysporum on cucumber seedlings were analyzed using Fisher's LSD $(P=0.05)$, although there is no implied linearity in the disease scales used $(20,25)$. Replicate experiments gave similar results.

\section{RESULTS}

Pathogenicity tests. A total of 23 of the 34 isolates of $F$. oxysporum from China were proved virulent under artificial inoculation conditions on cucumber cv. Knossos, but not on melon cv. Moulkeiko, sponge gourd, or pumpkin (Table 1), and caused symptoms resembling those incited by $F$. oxysporum f. sp. cucumerinum (22). The aggressiveness of these isolates ranged from low to high (Table 1). Based on disease symptoms after natural and artificial infection as well as on their virulence on cucumber (but not on melon, sponge gourd, and pumpkin), these 22 isolates were identified as $F$. oxysporum f. sp. cucumerinum. One isolate (9909-1) of $F$. oxysporum from the province of Heilongjiang (northeastern China), obtained in 1999 from a field cucumber crop with several diseased plants presenting root and stem rot symptoms, was virulent under artificial inoculation conditions on cucumber, melon, and sponge gourd but not on pumpkin (Table 1), causing symptoms resembling those incited by $F$. oxysporum f. sp. radicis-cucumerinum (22). The aggressiveness of this isolate was moderate (Table 1). Based on disease symptoms under natural infection and artificial inoculation conditions, and its virulence on cucumber, melon, and sponge gourd but not on pumpkin, the 9909-1 isolate was identified as $F$. oxysporum f. sp. radiciscucumerinum. The remaining 10 isolates, 9802, 9803, 9804, 9805, 9807, 9907-3, 0011, 0012, 0013, and 0015 (Table 1), were avirulent on cucumber, melon, sponge gourd, or pumpkin.

Vegetative compatibility tests. Based on the formation of strong complementary heterokaryons with the testers of VCG 0183 of $F$. oxysporum f. sp. cucumerinum, the Chinese isolates 0014, 0018, and 0019 were assigned to this VCG (Table 1), which also includes the Japanese isolates FOC-1 and Cu:5-0 (23). The Chinese isolates 9906-1, 9906-2, and 9906-3 were compatible with the testers of the Japanese isolate Tf-579, and the Chinese isolate 9909-2 was compatible with the testers of the Japanese isolate Tf-213 of VCG 018of F. oxysporum f. sp. cucumerinum (Table 1). According to the numbering system adopted by Puhalla (17) and further standardized by Kistler et al. (11), it is suggested that these VCGs should be assigned as 0184 and 0185 , respectively. A total of 14 Chinese isolates of $F$. oxysporum $\mathrm{f}$. sp. cucumerinum belonged to two new VCGs designated 0186 (11 isolates) and 0187 (three isolates). The isolate 9806 (2161-1) formed a single-member VCG, which was grouped into the artificial VCG 018-, and the isolate FHG 9801 was HSI (Table 1). The complementary nit mutants chosen as testers of VCG 0186 of F. oxysporum f. sp. cucumerinum were 9904-3-1 (nit1, parental isolate 9904-3) and 9904-3-2 (NitM, parental isolate 9904-3), and of VCG 0187 were $0020-2$ (nitl, parental isolate 0020) and 0020-6 (NitM, parental isolate 0020). The isolate $9909-1$ of $F$. oxysporum f. $\mathrm{sp}$. radicis-cucumerinum formed a strong heterokaryon with the tester AFu-15B-2 of VCG 0260 and the tester $\mathrm{AFu}-4 \mathrm{C}-8$ of VCG 0261 F. ox- ysporum f. sp. radicis-cucumerinum and was assigned to the VCG 0260/0261 (bridging group) (Table 1).

No heterokaryon formation was observed, either among avirulent Chinese isolates of $F$. oxysporum from cucumber, or between them and the tester strains of all VCGs of either $F$. oxysporum f. sp. cucumerinum or $F$. oxysporum f. sp. radicis-cucumerinum studied.

RAPD-PCR analysis. The quantitative data from RAPD-PCR experiments are presented in Table 2. All 10 Chinese isolates of $F$. oxysporum f. sp. cucumerinum belonging to VCGs 0183, 0184, 1085, 0187, and 018-, as well as the HSI isolate FHG 9801, were classified into the RAPD group III as established in a previous study (23), which also contained the reference isolate ATCC 36332 (race 3) from Japan (Table 1, Fig. 1). In contrast, all 10 Chinese isolates of $F$. oxysporum f. sp. сисumerinum assigned to VCG 0186 were classified into a new (23) RAPD group (XXI) (Table 1, Fig. 1). The isolate 9909-1 of $F$. oxysporum f. sp. radicis-cucumerinum was classified into the RAPD group I (Fig. 1), also previously established (23); this group also contained the reference isolates $\mathrm{AFu}-4$ and AF1-a from Crete (23). The avirulent isolates of $F$. oxysporum could be distinguished from the pathogenic isolates, because each isolate group belonged to a separate RAPD group (Table 1). The Chinese virulent isolates of both $F$. oxysporum f. sp. cucumerinum and $F$. oxysporum f. sp. radicis-cucumerinum could be distinguished from avirulent isolates of $F$. $o x$ ysporum from cucumber by both VCG and RAPD (Table 1).

\section{DISCUSSION}

The observed agreement in the identification of the 34 isolates of $F$. oxysporum from China obtained from diseased cucumber plants as $F$. oxysporum f. sp. $\mathrm{cu}$ cumerinum (23 isolates), F. oxysporum f. sp. radicis-cucumerinum (one isolate), and nonpathogenic $F$. oxysporum (10 isolates) by pathogenicity, VCG, and RAPD indicates the reliability and usefulness of these methods as diagnostic tools in population studies of $F$. oxysporum from cucumber.

The genetic relationships among the isolates of F. oxysporum f. sp. cucumerinum

Table 2. Primers used in this study and major random amplified polymorphic DNA (RAPD) fragments generated from the Fusarium oxysporum isolates tested ${ }^{\mathrm{a}}$

\begin{tabular}{lcccccc}
\hline \multirow{2}{*}{$\begin{array}{l}\text { Primer } \\
\text { code }\end{array}$} & Primer sequence & $\begin{array}{c}\text { Amplified } \\
\text { fragments }\end{array}$ & \multicolumn{4}{c}{ Fragments present in RAPD group } \\
\cline { 5 - 7 } & I & 9 & 5 & 8 & 7 & 7 \\
\hline OPA-01 & 5'-CAGGCCCTTC-3' & & II & III & XXI \\
OPB-01 & 5'-GTTTCGCTCC-3' & 5 & 5 & 3 & 4 & 5 \\
OPB-04 & 5'-GGACTGGAGT-3' & 6 & 4 & 6 & 6 & 6 \\
OPB-07 & 5'-GGTGACGCAG-3' & 9 & 9 & 7 & 7 & 7 \\
OPB-08 & 5'-GTCCACACGG-3' & 8 & 7 & 4 & 3 & 5 \\
OPB-14 & 5'-TCCGCTCTGG-3' & 10 & 2 & 3 & 3 & 6 \\
OPB-20 & 5'-GGACCCTTAC-3' & 8 & 3 & 5 & 5 & 5 \\
OPF-05 & 5'-CCGAATTCCC-3' & 7 & 4 & 6 & 6 & 6 \\
\hline
\end{tabular}

${ }^{a}$ In all experiments, only intense and reproducible bands were recorded. 
from China were complex, as reflected by the multiple VCGs and the two RAPD groups. A large number of VCGs is generally recorded in fungi that reproduce sexually (13), such as F. moniliforme (teleomorph Gibberella fujikuroi) (6). In contrast, fungi that reproduce only asexually, such as many of the formae speciales of $F$. oxysporum, generally have large VCGs that indicate a high degree of clonality (11). In F. oxysporum f. sp. cucumerinum, including the VCGs recently found (23), 11 VCGs have been identified so far. Considering the number of VCGs in 37 formae speciales of $F$. oxysporum, $F$. oxysporum f. sp. cucumerinum ranks third after $F$. oxysporum f. sp. cubense (24 VCGs) and $F$. oxysporum f. sp. vasinfectum (12 VCGs) (8). This demonstrates a high level of genetic diversity in $F$. oxgests that clonality is limited. This observation is in agreement with the results of Kim et al. (10), who reported that F. oxysporum f. sp. cucumerinum is the most diverse among the formae speciales of $F$. oxysporum infecting cucurbits.

Aggressiveness of isolates of $F$. oxysporum f. sp. cucumerinum in VCG 0186 was significantly lower than that of other VCGs (Table 1). These results suggest that VCG is associated with aggressiveness in this pathogen. A similar relation has also cumerinum in Korea (1).

About one-third of the Chinese isolates of $F$. oxysporum f. sp. cucumerinum belonged to VCGs 0183, 0184, 0185, 0187, and 018-, which as previously found, included all the Japanese isolates examined. ysporum f. sp. cucumerinum, which sugbeen reported for $F$. oxysporum f. sp. $c u$ -

Such a genetic similarity between Chinese and Japanese populations of $F$. oxysporum f. sp. cucumerinum is expected given the close proximity of China and Japan and the frequent exchanges of agricultural products that could allow distribution of genetically similar isolates. The occurrence of common VCGs could be explained by the spread of the pathogen from one country to the other through seeds, seedlings, diseased debris present in composts, and human activities.

Data suggesting that the isolate 9909-1 of $F$. oxysporum obtained from a diseased cucumber crop in the Shangzhi area of the province of Heilongjiang, in northeastern China, is $F$. oxysporum f. sp. radiciscucumerinum were obtained by isolation of the pathogen from naturally infected plants, the completion of Koch's postulates, and determination of the pathogen's host range. Its identification by pathogenicity was also supported by the VCG and RAPD data. Since its first record in Greece in 1989, F. oxysporum f. sp. radicis-cucumerinum has also been reported in several other countries in Europe and North America, causing significant yield losses $(23,24)$. To the best of our knowledge, this is the first report of this pathogen in China, and it appears to be the first record in Asia. Although the characterization and documentation of appearance of $F$. oxysporum f. sp. radiciscucumerinum in China was based on only one isolate, this result reflects the sampling density of the present study. Our samples were collected over a huge geographic area representing the entire country of China. In the future, increasing sampling density,

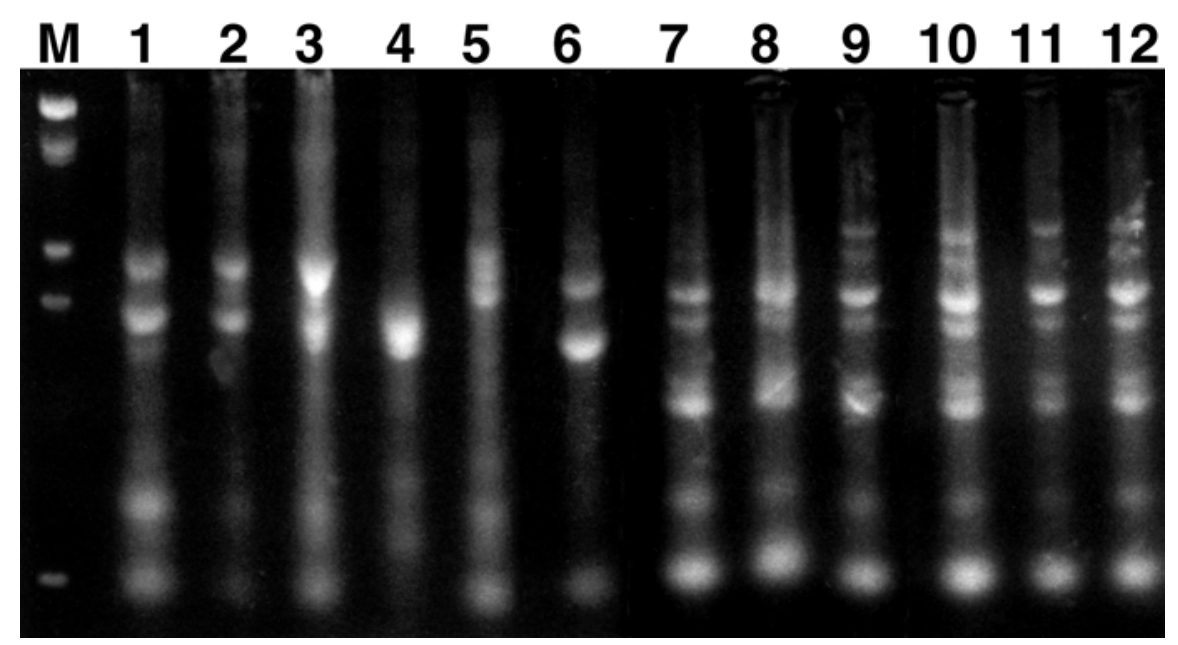

Fig. 1. Random amplified polymorphic DNA (RAPD) analysis from Fusarium oxysporum isolates with primer OPB-14. The products were separated on a $1.2 \%$ agarose gel stained with ethidium bromide and photographed under UV light. Lanes 1, 2, 3, and 6 represent RAPD group II isolates of $F$. oxysporum f. sp. cucumerinum, namely ATCC 16416, ATCC 36330, FOCU 56, and FOCU 57. Lane 4 represents RAPD group I isolates $F$. oxysporum f. sp. radicis-cucumerinum, namely 9909-1. Lane 5 represents RAPD group III isolates of $F$. oxysporum f. sp. cucumerinum, namely ATCC 36332 . Lanes $7,8,9,10,11$, and 12 represent RAPD group XXI isolates of $F$. oxysporum f. sp. cucumerinum, namely 9902-1, 9902-2, 9903-2, 9904-1, 9904-2, and 9905-0. Note the differences in the main bands between RAPD groups II and III, and the newly established group XXI. In lane M, a DNA marker was separated. The DNA fragments consist of 125 bp (bottom), 2,027 bp, 2,322 bp, 4,361 bp, 6,557 $\mathrm{bp}$, and higher (top). especially in the vicinity of the expected dissemination of the pathogen, is anticipated to verify the presence of $F$. $o x$ ysporum $\mathrm{f}$. sp. radicis-cucumerinum and to increase the number of reported incidents.

The isolate 9909-1 was assigned to RAPD group I and bridging VCG 0260/0261 of $F$. oxysporum f. sp. radiciscucumerinum. Earlier phylogenetic analysis of exclusively RAPD data from strains of cucurbitaceous hosts supported the monophyletic nature of this pathogen (23). Consequently, the cross-compatibility between nit mutants from strains of VCGs 0260 and 0261, which have the same RAPD pattern, indicates that $F$. oxysporum f. sp. radicis-cucumerinum may represent a single and recently diverged clonal lineage.

\section{LITERATURE CITED}

1. Ahn, I. P., Chung, H. S., and Lee, Y. H. 1998 Vegetative compatibility groups and pathogenicity among isolates of Fusarium oxysporum f. sp. cucumerinum. Plant Dis. 82:244-246

2. Armstrong, G. M., Armstrong, J. K., and Netzer, D. 1978. Pathogenic races of the cucumber-wilt Fusarium. Plant Dis. Rep. 62:824 828.

3. Booth, C. 1971. The genus Fusarium. CMI, Kew, Surrey, England.

4. Cerkauskas, R. F., and Brown, J. 2001. First report of Fusarium stem and root rot of greenhouse cucumber caused by Fusarium oxysporum f. sp. radicis-cucumerinum in Ontario. Plant Dis. 85:1028.

5. Correll, J. C., Klittich, C. J. R., and Leslie, J. F. 1987. Nitrate nonutilizing mutants of Fusarium oxysporum and their use in vegetative compatibility tests. Phytopathology 77:16401646.

6. Huang, R., Galperin, M., Levy, Y., and PerlTreves, R. 1997. Genetic diversity of Fusarium moniliforme detected by vegetative compatibility groups and random amplified polymorphic DNA markers. Plant Pathol. 46:871-881.

7. Jenkins, S. F., Jr., and Wehner, T. C. 1983 Occurrence of Fusarium oxysporum f. sp. $\mathrm{cu}$ cumerinum on greenhouse-grown Cucumis sativus seed stocks in North Carolina. Plant Dis. 67:1024-1025.

8. Katan, T., and Di Primo, P. 1999. Current status of Vegetative Compatibility in Fusarium oxysporum: Suppl.(1999). Phytoparasitica 27:273-277

9. Katan, T., Katan, J., Gordon, T. R., and Pozniak, D. 1994. Physiologic races and vegetative compatibility groups of Fusarium ox ysporum f. sp. melonis in Israel. Phytopathology 84:153-157.

10. Kim, D. H., Martyn, R. D., and Magill, C. W. 1993. Mitochondrial DNA (mtDNA)relatedness among formae speciales of $\mathrm{Fusa}$ rium oxysporum in the Cucurbitaceae. Phytopathology 83:91-97.

11. Kistler, H. C., Alabouvette, C., Baayen, R. P., Bentley, S., Brayford, D., Coddington, A. Correll, J., Daboussi, M.-J., Elias, K., Fernandez, D., Gordon, T. R., Katan, T., Kim, H. G., Leslie, J. F., Martyn, R. D., Migheli, Q., Moore, N. Y., O'Donnell, K., Ploetz, R. C., Rutherford, M. A., Summerell, B., Waalwijk, C., and Woo, S. 1998. Systematic numbering of vegetative compatibility groups in the plant pathogenic fungus Fusarium oxysporum. Phytopathology 88:30-32.

12. Leach, J. G., and Currence, T. M. 1938. Fusarium wilt of muskmelon in Minnesota. Minn Agric. Exp. Stn. Tech. Bull. 129:32. 
13. Leslie, J. F. 1993. Fungal vegetative compatibility. Annu. Rev. Phytopathol. 31:127-150.

14. Moreno, A., Alferez, A., Aviles, M., Dianez, F., Blanco, R., Santos, M., and Tello, J. C. 2001. First report of Fusarium oxysporum f. sp. radicis-cucumerinum on cucumber in Spain. Plant Dis. 85:1206.

15. Netzer, D., Niego, S., and Galun, E. 1977. A dominant gene conferring resistance to Fusarium wilt in cucumber. Phytopathology 67:525-527.

16. Pavlou, G. C., Vakalounakis, D. J., and Ligoxigakis, E. K. 2002. Control of root and stem rot of cucumber, caused by Fusarium oxysporum f. sp. radicis-cucumerinum, by grafting onto resistant rootstocks. Plant Dis. 86:379-382.

17. Puhalla, J. E. 1985. Classification of strains of Fusarium oxysporum on the basis of vegetative compatibility. Can. J. Bot. 63:179-183.

18. Punja, Z. K., Parker, M., Rose, S., and Louie, D. 1998. Occurrence of Fusarium crown and root rot, a new disease on greenhouse cucumbers in British Columbia, and methods for disease control. Cucurbitaceae 98:174-185.

19. Reverchon, S., Monnet, Y., Beliard, É., and Alabouvette, C. 2000. Du nouveau sur les fusarioses $\mathrm{du}$ concombre. Fusarium oxysporum f. sp. radicis-cucumerinum isolé pour la première fois en France. Phytoma 530:3638.

20. Snedecor, G. W., and Cochran, W. G. 1967. Statistical Methods. 6th ed. Iowa State University, Ames.

21. Vakalounakis, D. J. 1988. Diseases and pests of vegetable crops and their control. Technological Education Institute, Heraklio, Greece.

22. Vakalounakis, D. J. 1996. Root and stem rot of cucumber caused by Fusarium oxysporum f. sp. radicis-cucumerinum f. sp. nov. Plant Dis. 80:313-316.

23. Vakalounakis, D. J., and Fragkiadakis, G. A 1999. Genetic diversity of Fusarium ox ysporum isolates from cucumber: Differentiation by pathogenicity, vegetative compatibility, and RAPD fingerprinting. Phytopathology 89:161-168.

24. Vakalounakis, D. J., and Fragkiadakis, G. A. 2003. Plant pathobreeding with emphasis in tomato and cucurbits (in Greek). D. J. Vakalounakis, Heraklio, Greece.

25. Vakalounakis, D. J., and Williams, P. H. 1991 A cotyledon double inoculation technique for evaluating resistance to anthracnose (Colletotrichum orbiculare) and scab (Cladosporium cucumerinum) in cucumber. Ann. Appl. Biol. 118:273-282. 